\title{
Denis Bjaï, Rabelais et le dialogue d'idées: Pantagruel chez les Papimanes (Quart Livre, 48-54)
}

\section{Michele Mastroianni}

\section{(2) OpenEdition}

1 Journals

\section{Edizione digitale}

URL: http://journals.openedition.org/studifrancesi/7866

DOI: 10.4000/studifrancesi.7866

ISSN: 2421-5856

\section{Editore}

Rosenberg \& Sellier

\section{Edizione cartacea}

Data di pubblicazione: 1 juillet 2009

Paginazione: $379-340$

ISSN: 0039-2944

\section{Notizia bibliografica digitale}

Michele Mastroianni, «Denis Bjaï, Rabelais et le dialogue d'idées: Pantagruel chez les Papimanes (Quart Livre, 48-54)», Studi Francesi [Online], 158 (LIII | II) | 2009, online dal 30 novembre 2015, consultato il 13 janvier 2021. URL: http://journals.openedition.org/studifrancesi/7866 ; DOI: https://doi.org/10.4000/ studifrancesi.7866

Questo documento è stato generato automaticamente il 13 janvier 2021.

\section{(c)}

Studi Francesi è distribuita con Licenza Creative Commons Attribuzione - Non commerciale - Non opere derivate 4.0 Internazionale. 


\title{
Denis Bjaï, Rabelais et le dialogue d'idées: Pantagruel chez les Papimanes (Quart Livre, 48-54)
}

\author{
Michele Mastroianni
}

\section{NOTIZIA}

DENIS BJAÏ, Rabelais et le dialogue d'idées: Pantagruel chez les Papimanes (Quart Livre, 48-54), «Revue des Amis de Ronsard», XXI (2008), pp. 95-113.

1 Analizzando i capitoli consacrati, nel Quart Livre, allo scalo nell'isle des Papimanes capitoli di violenta satira antipapale -, l'A. da un lato illustra la costruzione teatrale delle parti dialogiche, ove Rabelais metterebbe in atto dei precisi dispositivi che sono quelli della farce, dall'altro evidenzia come l'uso di un procedimento linguistico evocante il dialogo della commedia, si accompagni a precise caratterizzazioni dei personaggi, che usano tecniche diverse - anche retoriche - nel controbattere da una prospettiva evangelica le aberrazioni teologiche e liturgiche dei Papimanes. 